\title{
Cytochrome Formation, Oxygen-induced Proton Extrusion and Respiratory Activity in Streptococcus faecalis var. zymogenes Grown in the Presence of Haematin
}

\author{
By G. G. PRITCHARD* AND J. W. T. WIMPENNY \\ Microbiology Department, University College, Cardiff CF2 ITA
}

(Received 8 August 1977)

\begin{abstract}
Streptococcus faecalis var. zymogenes was grown in oxygen-limited continuous culture in a lactate/tryptone/yeast extract medium containing $7 \cdot 5 \mu \mathrm{g}$ haematin $\mathrm{ml}^{-1}$. Low temperature difference spectra of whole organisms and washed membranes showed two peaks in the cytochrome $b$ region, at $558 \mathrm{~nm}$ and $562 \mathrm{~nm}$, and a peak at $627 \mathrm{~nm}$ indicative of a $d$-type cytochrome. A CO-binding cytochrome was also present in the haematin-grown bacteria. These cytochromes were not detected in bacteria grown without haematin. The haematingrown bacteria produced proton pulses in a weakly buffered medium when pulsed with oxygen-saturated buffer. The average $\rightarrow \mathrm{H}^{+} / \mathrm{O}$ ratio of such pulses was $\mathrm{I} \cdot 4$ and they were abolished by carbonyl cyanide $m$-chlorophenylhydrazone (CCCP). The haematin-grown bacteria had a high activity of particulate NADH oxidase, at least 10 times that of bacteria grown without haematin. They also had a high lactate $Q_{\mathrm{O}_{2}}$ which was strongly inhibited by CCCP and gramicidin whereas bacteria grown without haematin had a very low lactate $Q_{\mathrm{O}_{z}}$ largely insensitive to the uncoupling agents. The glucose $Q_{\mathrm{O}_{2}}$ was similar in bacteria grown in the presence or absence of haematin but was stimulated by uncoupling agents in haematingrown organisms and slightly inhibited by these agents in organisms grown without haematin. These results confirm earlier findings of the ability of $S$. faecalis to form a functional cytochrome system in the cell membrane when supplied with haematin and show that electron transport to oxygen by such a system is coupled to proton translocation.
\end{abstract}

\section{INTRODUCTION}

Recent studies (Bryan-Jones \& Whittenbury, I969; Sijpesteijn, 1970; Ritchey \& Seeley, 1974) have revealed that certain lactic acid bacteria, formerly thought to be incapable of cytochrome synthesis, can form a functional electron transport system when grown in media containing haematin. Among streptococci, this ability is apparently restricted to Streptococcus faecalis and some strains of $S$. lactis (Ritchey \& Seeley, 1976) but has also been reported in Leuconostoc mesenteroides NCIB99I7 (Sijpesteijn, I970). The evidence for the presence of a functional, membrane-bound electron transport system in the haematingrown bacteria includes: sensitivity of the respiration to cyanide, antimycin $\mathrm{A}$ and $n$-heptyl4-hydroxyquinoline- $N$-oxide (HOQNO); membrane location of much of the NADH oxidase activity; ATP formation coupled to NADH oxidation by cell membrane particles; and spectroscopy of whole organisms or membranes. The published spectra (Bryan-Jones \& Whittenbury, 1969; Ritchey \& Seeley, 1974) indicate an $\alpha$-band around $560 \mathrm{~nm}$ indicative of a $b$-type cytochrome but show no evidence of other cytochromes. Sijpesteijn (1970)

* Present address: Department of Chemistry, Biochemistry and Biophysics, Massey University, Palmerston North, New Zealand. 
reported the presence of peaks at $423 \mathrm{~nm}$, at 556 to $558 \mathrm{~nm}$ and at 628 to $630 \mathrm{~nm}$ in S. lactis grown in the presence of haematin but the spectra were not published.

The present study was undertaken, firstly, to characterize more fully the spectra of the cytochromes formed in the presence of haematin and, secondly, to investigate the capacity of haematin-grown bacteria to couple respiration to proton translocation. Observations on the effect of proton-translocating ionophores on the respiration of haematin-grown cells are also reported. The bacteria were grown in oxygen-limited continuous culture using a nonfermentable substrate, lactate, as the energy source to minimize the possibility of catabolite repression and to enhance the difference between bacteria grown with and without haematin.

\section{METHODS}

Organism. Streptococcus faecalis var. zymogenes strain TR was kindly supplied by Professor H. W. Seeley, Cornell University, Ithaca, U.S.A. It was maintained on a lactate/tryptone/yeast extract agar of the same composition as the liquid medium described below. The maintenance medium contained to $\mu \mathrm{g}$ haematin $\mathrm{ml}^{-1}$.

Growth conditions. The medium used contained $\left(\mathrm{g}^{-1}\right)$ : tryptone (Difco), Io; yeast extract (Difco), 6.5; $\mathrm{KH}_{2} \mathrm{PO}_{4}, 0.5 ; \mathrm{MgSO}_{4} \cdot 7 \mathrm{H}_{2} \mathrm{O}, 0.2 ; \mathrm{MnCl}_{2} .4 \mathrm{H}_{2} \mathrm{O}, 0.05 ;$ sodium DL-lactate (70 \% solution, $\left.\mathrm{BDH}\right), 12 \cdot 8$. The medium was adjusted to $\mathrm{pH} 6.7$ and sterilized in $\mathrm{I} 5 \mathrm{l}$ batches at $\mathrm{I} 2 \mathrm{I}{ }^{\circ} \mathrm{C}$ for $60 \mathrm{~min}$. For haematin-containing media, haematin ( $\mathrm{I} \mathrm{m} \mathrm{ml}^{-1}$ ) in $0.1 \mathrm{M}-\mathrm{NaOH}$ was sterilized by membrane filtration and added aseptically to give $7.5 \mu \mathrm{g} \mathrm{ml}^{-1}$. The organism was grown in continuous culture in a CCI 500 chemostat (LH Engineering Co., Stoke Poges, Buckinghamshire) at $30^{\circ} \mathrm{C}$. The culture volume was 2.251 and the dilution rate was $0.083 \mathrm{~h}^{-1}$. Foaming was prevented by automatic addition every $30 \mathrm{~min}$ of $0.2 \mathrm{ml}$ of a $\mathrm{I}: 4$ dilution of silicone antifoam $\mathrm{RD}$ (Dow Corning, Barry, South Glamorgan). The $\mathrm{pH}$ was controlled by automatic addition of $2.5 \mathrm{M}-\mathrm{NaOH}$. The culture was sparged with an air $/ \mathrm{N}_{2}$ mixture containing $\mathrm{O}_{2}$ at a partial pressure of $10 \mathrm{mmHg}(\mathrm{I} \cdot 33 \mathrm{kPa})$ at a gas flow rate of $750 \mathrm{ml} \mathrm{min}^{-1}$. The culture was stirred at 425 rev. $\mathrm{min}^{-1}$, giving a mass transfer coefficient $\left(k_{\mathrm{L}} a\right)$ for this fermenter of $3^{6 \mathrm{~h}^{-1}}$ at the gas flow rate used. No dissolved $\mathrm{O}_{2}$ was detected by the oxygen electrode and studies at different $p_{\mathrm{O}_{2}}$ levels showed that, at the partial pressure used, oxygen was the growthlimiting factor. The culture was maintained for $48 \mathrm{~h}$ to obtain a steady state as indicated by $\mathrm{pH}$ and extinction measurements. Samples were examined microscopically and by plating to establish culture purity. Samples for respiration measurement, proton-pulse studies and for cytochrome and enzyme determination were collected in an ice-cold receiver. Bacteria were harvested by centrifuging (10000 $\mathrm{g}$, I0 min) and washed twice in $20 \mathrm{~mm}$-phosphate buffer $\mathrm{pH} 7 \cdot 0$.

Oxygen uptake measurement. The harvested bacteria were resuspended in $100 \mathrm{~mm}$-phosphate buffer $\mathrm{pH} 7 \cdot 0$ to a density of between 5 and $10 \mathrm{mg}$ dry $\mathrm{wt} \mathrm{ml}^{-1}$. Oxygen uptake was determined in an oxygen electrode (Rank Bros, Bottisham, Cambridgeshire) at $30^{\circ} \mathrm{C}$ in the presence of $2.5 \mathrm{mM}$-sodium DL-lactate or $2.5 \mathrm{~mm}$ glucose. The effects of uncoupling agents were examined by adding $\mathrm{I}$ or $2 \mu \mathrm{l}$ of either carbonyl cyanide $m$-chlorophenylhydrazone (CCCP) or gramicidin $\mathrm{D}$ (both at $0.5 \mathrm{mg} \mathrm{ml}^{-1}$ in methanol). At the concentration used, methanol had no effect on oxygen uptake.

Determination of enzyme activities. The harvested bacteria were disrupted in a Hughes press (Hughes, 195I) cooled to $-30^{\circ} \mathrm{C}$ with dry ice. The homogenate was fractionated into a thoroughly washed cell wall/ membrane fraction and a high speed supernatant fraction [from which particulate matter had been removed by centrifuging $\left(90000 \mathrm{~g}, 2 \mathrm{~h}, \mathrm{o}^{\circ} \mathrm{C}\right)$ ] according to the procedure of Gray et al. (I966).

Reaction mixtures $(3.0 \mathrm{ml})$ for enzyme assays had the following compositions.

NADH oxidase: $275 \mu \mathrm{mol}$ potassium phosphate buffer $\mathrm{pH} 7.0 ; 0.25 \mu \mathrm{mol} \mathrm{NADH} ; 0.2 \mathrm{ml}$ of either cell wall $/$ membrane suspension (40 to $60 \mu \mathrm{g}$ protein) or supernatant fraction (200 to $400 \mu \mathrm{g}$ protein). The rate of decrease in extinction at $340 \mathrm{~nm}$ was measured.

NADH peroxidase: $270 \mu \mathrm{mol}$ sodium acetate buffer $\mathrm{pH} 5.4 ; 0.25 \mu \mathrm{mol} \mathrm{NADH} ; 5 \mu \mathrm{mol} \mathrm{H}_{2} \mathrm{O}_{2} ; 0.2 \mathrm{ml}$ supernatant fraction ( 50 to $100 \mu \mathrm{g}$ protein). Residual NADH oxidase activity at $\mathrm{pH} 5.4$ was measured before adding the peroxide and peroxidase activity was determined from the difference in rates of NADH oxidation before and after peroxide addition.

NADH: dichlorophenolindophenol (DCPIP) oxidoreductase: $265 \mu \mathrm{mol}$ Tris $/ \mathrm{HCl}$ buffer $\mathrm{pH} 7 \cdot 4 ; 0.25 \mu \mathrm{mol}$ $\mathrm{NADH} ; 0 . \mathrm{I} \mu \mathrm{mol}$ DCPIP; $0.2 \mathrm{ml}$ cell wall/membrane suspension (IO to I $2 \mu \mathrm{g}$ protein). The decrease in extinction at $600 \mathrm{~nm}$ was measured.

Protein was determined by the method of Lowry et al. (I95I).

Cytochromes. Cytochrome spectra of the cell wall/membrane fraction were determined at room temperature and in liquid nitrogen $\left(-196^{\circ} \mathrm{C}\right)$; whole organism spectra were determined in liquid nitrogen. Room temperature spectra of the membrane suspension ( $\mathrm{I}$ to $\mathrm{I} \cdot 5 \mathrm{mg}$ protein $\mathrm{ml}^{-1}$ ) in $20 \mathrm{mM}$-phosphate buffer 
$\mathrm{pH} 7.0$ were determined in I $\mathrm{ml}$ cuvettes with a $\mathrm{I} \mathrm{cm}$ light path in a Cary $\mathrm{I} 4$ spectrophotometer. Difference spectra were recorded for samples reduced with dithionite and read against samples oxidized either with air or with a few crystals of potassium ferricyanide. For $\mathrm{CO}$-difference spectra, samples reduced with dithionite were gassed with $\mathrm{CO}$ for $60 \mathrm{~s}$ and spectra were determined using a dithionite-reduced sample as reference.

Spectra at $-196^{\circ} \mathrm{C}$ of whole organism suspensions (approx. $50 \mathrm{mg} \mathrm{dry} \mathrm{wt} \mathrm{ml}^{-1}$ ) or of cell wall/membrane suspensions $\left(5 \mathrm{mg}\right.$ protein $\mathrm{ml}^{-1}$ ) in $0.8 \mathrm{M}$-mannitol were determined using $0.2 \mathrm{ml}$ cuvettes with a $2 \mathrm{~mm}$ light path. Difference spectra were recorded for samples reduced with lactate (about $2 \mu 170 \%$ sodium lactate solution per $0.2 \mathrm{ml}$ suspension) or with a few crystals of dithionite and read against samples oxidized with air or with a few crystals of ferricyanide. Samples were immersed in liquid nitrogen and maintained at this temperature by immersion of the base of the cuvette holder in a small Dewar flask in the turbid sample compartment of a Unicam SPr 800 spectrophotometer.

Proton pulse measurement. Oxygen-induced proton pulses were determined by a procedure similar to that described by Scholes \& Mitchell (1970). The harvested bacteria were thoroughly washed twice in buffer ( $140 \mathrm{mM}-\mathrm{KCl} / \mathrm{I} \mathrm{mm}$-glycylglycine $\mathrm{pH} \mathrm{7.0)}$. They were resuspended in this buffer to a density of about $\mathrm{IO} \mathrm{mg}$ dry wt ml ${ }^{-1}$ and carbonic anhydrase (I00 $\mu \mathrm{l}$ of a $5 \mathrm{mg} \mathrm{m}^{-1}$ solution) was added. The suspension was placed in a Perspex vessel maintained at $30^{\circ} \mathrm{C}$ (a Rank oxygen electrode vessel with a magnetic stirrer was used for this purpose). The $\mathrm{pH}$ was measured with a combination glass/reference electrode (Electronic Instruments, Richmond, Surrey) inserted tightly through a silicone rubber stopper so that the suspension completely filled the chamber. Additions were made by means of a Hamilton syringe inserted between the vessel wall and the stopper. The electrode output was measured and amplified by a Vibron Electrometer (33B-2) and $\mathrm{pH}$ measuring unit ( $\left.\mathrm{C}_{33} \mathrm{~B}-2\right)$ (Electronic Instruments). Approximately $30 \mathrm{~min}$ was allowed for the suspension to become completely anaerobic. By the end of this pre-incubation period, the $\mathrm{pH}$ drift had settled to a very slow rate of change and the $\mathrm{pH}$ was brought back to 7.0 by addition of $\mathrm{NaOH}$. Sodium DL-lactate $(50 \mu \mathrm{l}, \mathrm{O} . \mathrm{I} \mathrm{M})$ was added and a further 5 to $10 \mathrm{~min}$ was allowed for the $\mathrm{pH}$ drift to settle again. Valinomycin was then added to give concentrations between 0.5 and $5.0 \mu \mathrm{g} \mathrm{ml}^{-1}$, followed by $50 \mu \mathrm{l} \mathrm{KCl} / \mathrm{glycylglycine} \mathrm{buffer} \mathrm{saturated}$ with pure oxygen at $30{ }^{\circ} \mathrm{C}$. Proton production was measured by calibrating with Io $\mu$ l additions of Io $\mathrm{mm}$ $\mathrm{HCl}$. Pulse height was measured by extrapolating the pulse slope and the subsequent drift slope back to the point of intersection.

Chemicals. Haematin, valinomycin, CCCP, gramicidin D, NADH and carbonic anhydrase were obtained from Sigma. All other chemicals, except where specified, were obtained from BDH.

\section{RESULTS}

\section{Enzyme activities}

Four NADH-oxidizing enzyme systems were measured in bacteria grown with and without haematin (Table I). Bacteria grown with haematin had a high membrane-bound NADH oxidase activity whereas membranes of the bacteria grown without added haematin had a very low NADH oxidase activity. Possibly the low activity of particulate NADH oxidase in organisms grown without haematin represents adsorbed soluble NADH oxidase activity in spite of the thorough washing of the membrane fraction (three washes in phosphate buffer) since a low level of NADH peroxidase was also present in the membrane fraction of these bacteria. However, the oxidase:peroxidase ratio was higher in the membrane fraction than in the soluble fraction from bacteria grown without haematin.

In contrast to the NADH oxidase activity, the membrane-bound NADH:DCPIP oxidoreductase activity was higher in membranes from the bacteria grown without haematin than in the haem-grown bacteria. The soluble NADH oxidase activity was also higher in bacteria grown without haematin, as found in a previous study (Ritchey \& Seeley, 1974). NADH peroxidase activity was unaltered by growth in a haematin-containing medium. No catalase activity was detected in bacteria grown with or without haematin.

\section{Cytochromes}

Reduced minus oxidized difference spectra of the cell wall/membrane fraction of haematingrown bacteria showed a Soret peak at $432 \mathrm{~nm}$ and $\alpha$-peaks at 562 and $632 \mathrm{~nm}$ when measured at room temperature (Fig. I). The $562 \mathrm{~nm}$ peak was superimposed on a broad absorption region between 500 and $600 \mathrm{~nm}$ which is probably due to adsorbed haematin, since haematin in solution also shows this broad absorbance with a $\lambda_{\max }$ at $580 \mathrm{~nm}$ (Fig. 1 ). 
Table I. Activities of NADH-oxidizing enzyme systems in S. faecalis var. zymogenes grown with and without haematin

Enzyme activities are expressed as $\mu$ mol NADH oxidized min $^{-1}$ (mg protein $)^{-1}$.

$\begin{array}{lcc}\text { Enzyme system } & \begin{array}{c}\text { Bacteria grown } \\ \text { with haematin } \\ \left(7.5 \mu \mathrm{g} \mathrm{ml}^{-1}\right.\end{array} & \begin{array}{c}\text { Bacteria grown } \\ \text { without } \\ \text { haematin }\end{array} \\ \begin{array}{l}\text { Particulate NADH oxidase } \\ \text { (in cell wall/membrane fraction) }\end{array} & 2 \cdot 3 \mathrm{I} & 0.19 \\ \begin{array}{c}\text { Soluble NADH oxidase } \\ \text { (in 90000 } \mathrm{g} \text { supernatant) }\end{array} & 0.18 & 0.48 \\ \begin{array}{l}\text { Soluble NADH peroxidase } \\ \text { Particulate NADH:DCPIP } \\ \text { oxidoreductase }\end{array} & 0.84 & 0.89 \\ & 2 \cdot 15 & 4.02\end{array}$

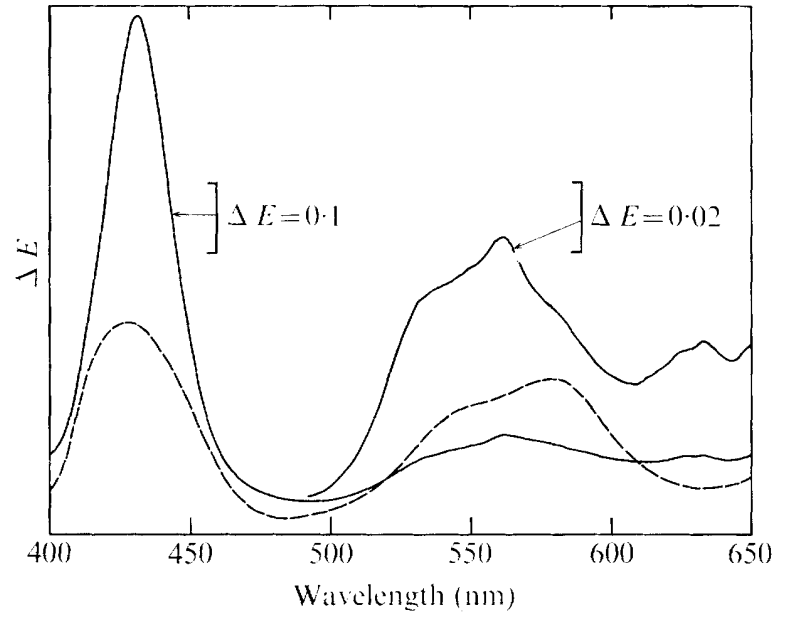

Fig. I. Dithionite-reduced minus air-oxidized difference spectra at room temperature of the cell wall/membrane fraction $\left(\mathrm{I} \cdot 75 \mathrm{mg}\right.$ protein $\left.\mathrm{ml}^{-1}\right)$ of $S$. faecalis var. zymogenes grown in the presence of haematin (-), and of a haematin solution (10 $\mu \mathrm{g} \mathrm{ml}^{-1} ;---$ ). Both the membrane suspension and the haematin solution were in $20 \mathrm{~mm}$-phosphate buffer $\mathrm{pH} 7 \cdot 0$.

The shoulder on the cell wall/membrane spectrum at $580 \mathrm{~nm}$ was presumably due to this haematin absorbance.

The liquid nitrogen difference spectrum of whole organisms (Fig. 2) grown in the absence of haematin showed a trough between 460 and $480 \mathrm{mn}$ presumably due to flavoprotein absorbance but no trace of any cytochrome peaks. In the haematin-grown organisms, the intense flavoprotein absorbance largely obscured the Soret peak of the cytochromes but a small peak was evident at $430 \mathrm{~nm}$. Two $b$-type cytochrome peaks were evident in the $\alpha$-band spectrum, at 558 and $562 \mathrm{~nm}$. This double peak was present in the low temperature spectra of organisms of this strain of $S$. faecalis grown under a wide range of aeration conditions. It was also present in the low temperature spectrum of the cell membrane fraction, again superimposed on an adsorbed haematin absorbance (Fig. 2). Membranes obtained from bacteria grown in the absence of haematin were suspended in a haematin solution ( $10 \mu \mathrm{g}$ $\mathrm{ml}^{-1}$ ) at $\mathrm{pH} 7.0$ for $2 \mathrm{~h}$ and then sedimented, washed and resuspended in $0.8 \mathrm{M}$-mannitol. The liquid nitrogen difference spectrum of these membranes (Fig. 2) showed the broad peak due to adsorbed haematin with a $\lambda_{\max }$ at $572 \mathrm{~nm}$. There was no evidence of either the cytochrome $b$ or the cytochrome $d$ peaks.

The CO-difference spectrum (Fig. 3) showed a peak at $417 \mathrm{~nm}$ characteristic of an $o$-type cytochrome. The CO-difference spectrum of membranes obtained from bacteria grown 


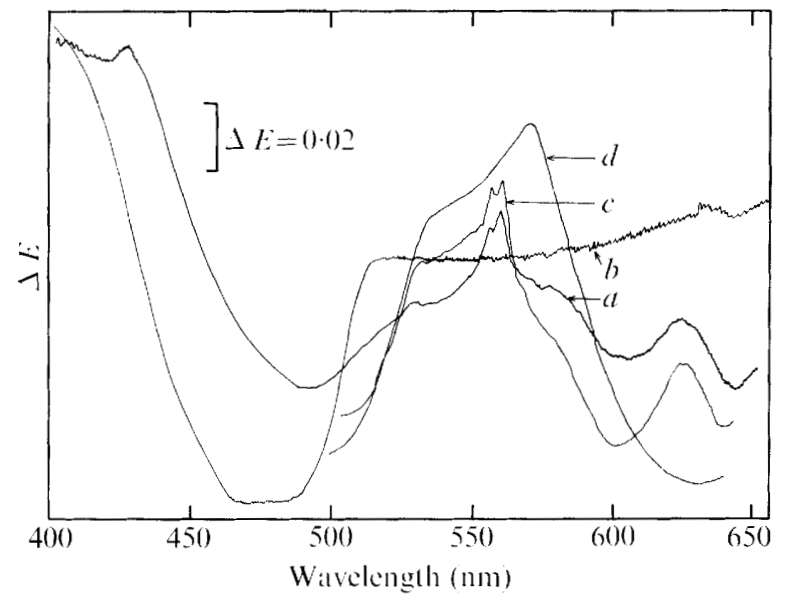

Fig. 2. Reduced minus oxidized difference spectra of whole organisms and of the cell wall/membrane fraction of $S$. faecalis var. zymogenes in $0.8 \mathrm{M}$-mannitol at $-196^{\circ} \mathrm{C}$. (a) Dithionite-reduced minus air-oxidized spectrum of haematin-grown organisms $\left(25 \mathrm{mg}\right.$ dry $\mathrm{wt} \mathrm{ml}^{-1}$ ). (b) Dithionite-reduced minus air-oxidized spectrum of organisms grown without haematin $\left(50 \mathrm{mg}\right.$ dry wt $\left.\mathrm{ml}^{-1}\right)$. (c) Dithionite-reduced minus ferricyanide-oxidized spectrum of the cell wall/membrane fraction ( $5 \mathrm{mg}$ protein $\mathrm{ml}^{-1}$ ) from haematin-grown organisms. (d) Dithionite-reduced minus ferricyanideoxidized spectrum of the cell wall/membrane fraction $\left(5 \mathrm{mg}\right.$ protein $\mathrm{ml}^{-1}$ ) of organisms grown without haematin after the membranes had been suspended in haematin solution ( $10 \mu \mathrm{g} \mathrm{ml}^{-1}, \mathrm{pH}_{7} \cdot 0$ ) for $2 \mathrm{~h}$, then sedimented, washed and resuspended in $0.8 \mathrm{M}$-mannitol.

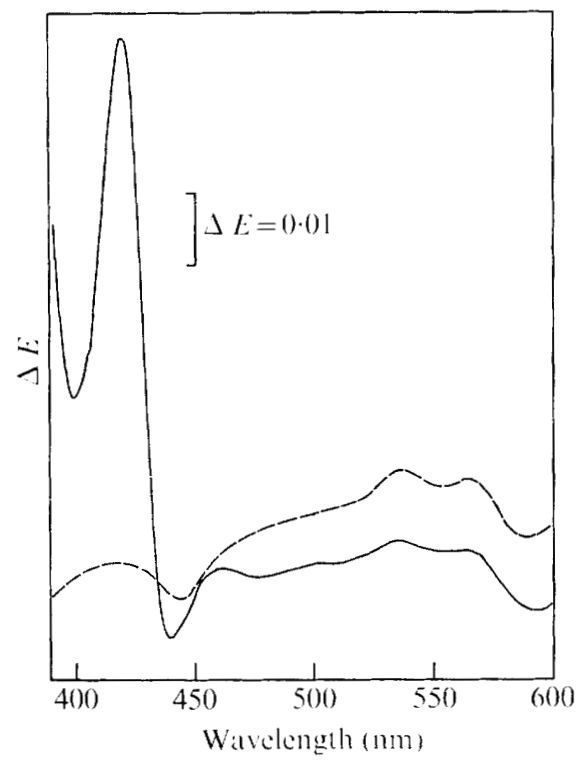

Fig. 3. Carbon monoxide difference spectra of the cell wall/membrane fraction prepared from $S$. faecalis var. zymogenes grown in the presence of haematin $(-$ ) and of membranes from organisms grown without haematin to which haematin has been adsorbed from solution (-- -). Both suspensions had a density of $\mathrm{I} \cdot \mathrm{O}$ to $\mathrm{I} \cdot 2 \mathrm{mg}$ protein $\mathrm{ml}^{-\mathbf{I}}$.

without haematin and then allowed to adsorb haematin showed no such intense absorbance at $417 \mathrm{~nm}$. The peaks at 535 and $570 \mathrm{~nm}$ may be due to haematin itself since they can be obtained in the CO-difference spectrum of a haematin solution. 


\section{Respiratory activity and sensitivity to uncoupling agents}

Haematin-grown bacteria oxidized lactate to to 20 times faster than did bacteria grown in the absence of haematin (Table 2). The lactate respiration of haematin-grown bacteria was strongly inhibited by low concentrations of the uncoupling ionophores CCCP and gramicidin D. The low rate of lactate respiration obtained in bacteria grown without added haematin was only slightly inhibited by these uncoupling agents. In contrast to lactate respiration, glucose respiration was only about $20 \%$ higher in haematin-grown bacteria than in those grown without haematin. Furthermore, CCCP and gramicidin D stimulated glucose respiration in haematin-grown bacteria by between 16 and $27 \%$. In the bacteria grown without haematin these uncoupling agents inhibited glucose-induced oxygen uptake by Io to $20 \%$. These effects of uncoupling agents on the respiration of haematin-grown bacteria were very reproducible. A second culture of haematin-grown bacteria gave the same response pattern: 70 to $75 \%$ inhibition of lactate respiration and 20 to $25 \%$ stimulation of glucose respiration by $\mathrm{CCCP}$ and gramicidin $\mathrm{D}$.

\section{Oxygen-induced proton pulse production}

When an anaerobic suspension of washed, haematin-grown bacteria suspended in very weak buffer (I mM-glycylglycine/140 $\mathrm{mm}-\mathrm{KCl}$ ) in the presence of lactate and valinomycin was injected with a $50 \mu \mathrm{l}$ pulse of oxygen-saturated buffer, a rapid acidification of the medium occurred (Fig. 4). Maximum acidification was obtained in the presence of I mm-lactate and $0.5 \mu \mathrm{g}$ valinomycin $\mathrm{ml}^{-1}$; higher concentrations of either of these did not increase the size of the proton pulse. With increasing incubation time there was a slight decrease in pulse size; this was probably due to leakage of compounds from the cells which increase the buffering capacity of the suspension medium since pulses produced by injection of standard acid were correspondingly decreased. The proton pulses were eliminated by addition of CCCP. Calculation of the $\rightarrow \mathrm{H}^{+} / \mathrm{O}$ stoicheiometry from 22 pulses gave a value of $\mathrm{I} \cdot 37 \pm 0 \cdot 27$. Bacteria grown without added haematin normally showed no proton pulses on addition of oxygensaturated buffer. One batch of bacteria grown in the absence of haematin at a very low $p_{\mathrm{O}_{2}}(4 \mathrm{mmHg})$ did produce small and rather sluggish proton pulses. This particular batch of cells had a higher rate of lactate respiration [ I $\mathrm{nmol} \mathrm{min}^{-1}$ (mg dry wt) ${ }^{-1}$ ] than those used in the present study.

\section{DISCUSSION}

Our results confirm earlier findings (Bryan-Jones \& Whittenbury, 1969; Ritchey \& Seeley, 1974) that some strains of $S$. faecalis can synthesize a functional, membrane-bound cytochrome system when grown in the presence of added haematin. In addition to the $b$-type cytochrome there are two possible oxidase components, a cytochrome $d_{630}$ and the CObinding cytochrome. The production of proton pulses by such cells when supplied with oxygen indicates that the cytochrome system is vectorially oriented in the membrane, as in other cytochrome-containing aerobes, so that electron transport to oxygen may be chemiosmotically coupled to phosphorylation or to transport processes. The magnitude of the proton pulse produced in response to a given amount of oxygen (the $\rightarrow \mathrm{H}^{+} / \mathrm{O}$ ratio) has been used to estimate the $\mathrm{P} / \mathrm{O}$ ratio of bacterial cells (Lawford \& Haddock, 1973; JJones et al., 1975) on the assumption that two $\mathrm{H}^{+}$are involved in the production of one ATP via the protontranslocating ATPase system. The average $\rightarrow \mathrm{H}^{+} / \mathrm{O}$ ratio obtained with the haematin-grown bacteria in the present study was $\mathrm{I} \cdot 4$ which corresponds to a $\mathrm{P} / \mathrm{O}$ ratio of $0 \cdot 7$. From a comparison of the molar growth yield on mannitol and glucose, Ritchey \& Seeley (I974) calculated a $\mathrm{P} / \mathrm{O}$ ratio of 0.75 for this same strain of $S$. faecalis. Direct measurement of the $\mathrm{P} / \mathrm{O}$ ratio using phosphorylating membrane particles yielded lower values of between 0.3 and 0.4 (Bryan-Jones \& Whittenbury, 1969; Ritchey \& Seeley, 1974) but such low values are commonly obtained from in vitro measurements with bacterial membranes (Gel'man, Lukoyanova \& Ostrovskii, I967). Calculation of the $\mathrm{P} / \mathrm{O}$ ratio from the $\rightarrow \mathrm{H}^{+} / \mathrm{O}$ value does 
Table 2. Effect of uncoupling agents on lactate and glucose oxidation by

$S$. faecalis var. zymogenes grown with and without haematin

Oxygen uptake rates of washed suspensions of bacteria grown in a lactate/tryptone/yeast extract medium ( $Q_{\mathrm{O}_{2}}$ values) are expressed as $\mathrm{nmol} \mathrm{O}_{2} \min ^{-1}\left(\mathrm{mg} \text { dry } \mathrm{wt}^{-1}\right)^{-1}$.

\begin{tabular}{|c|c|c|}
\hline Oxidation substrate and treatment & $\begin{array}{l}\text { Bacteria grown } \\
\text { with haematin } \\
\left(7 \cdot 5 \mu \mathrm{g} \mathrm{ml}^{-1}\right)\end{array}$ & $\begin{array}{l}\text { Bacteria grown } \\
\text { without } \\
\text { haematin }\end{array}$ \\
\hline $\begin{array}{l}\text { Na DL-lactate }(2.5 \mathrm{~mm}) \\
\text { Lactate }+ \text { CCCP }\left(0.5 \mu \mathrm{g} \mathrm{ml}^{-1}\right) \\
\text { Lactate }+ \text { CCCP }\left(\mathrm{I} \cdot 0 \mu \mathrm{g} \mathrm{ml}^{-1}\right) \\
\text { Lactate }+ \text { gramicidin D }\left(0.5 \mu \mathrm{g} \mathrm{ml}^{-1}\right)\end{array}$ & $\begin{array}{r}106 \cdot 2 \\
51 \cdot 0 \\
24 \cdot 2 \\
26 \cdot 7\end{array}$ & $\begin{array}{l}4 \cdot 3 \\
3 \cdot 7 \\
3 \cdot 2 \\
3 \cdot 4\end{array}$ \\
\hline $\begin{array}{l}\text { Glucose }(2.5 \mathrm{mM}) \\
\text { Glucose }+ \text { CCCP }\left(0.5 \mu \mathrm{g} \mathrm{ml}^{-1}\right) \\
\text { Glucose }+ \text { CCCP }\left(\mathrm{I} \cdot 0 \mu \mathrm{g} \mathrm{ml}^{-1}\right) \\
\text { Glucose }+ \text { gramicidin D }\left(0.5 \mu \mathrm{g} \mathrm{ml}^{-1}\right)\end{array}$ & $\begin{array}{l}103 \cdot 5 \\
13 I \cdot 0 \\
131 \cdot 0 \\
126 \cdot 5\end{array}$ & $\begin{array}{l}80 \cdot 0 \\
\mathrm{ND} \\
60 \cdot 4 \\
7 \mathrm{I} \cdot \mathrm{I}\end{array}$ \\
\hline
\end{tabular}

ND, Not determined.

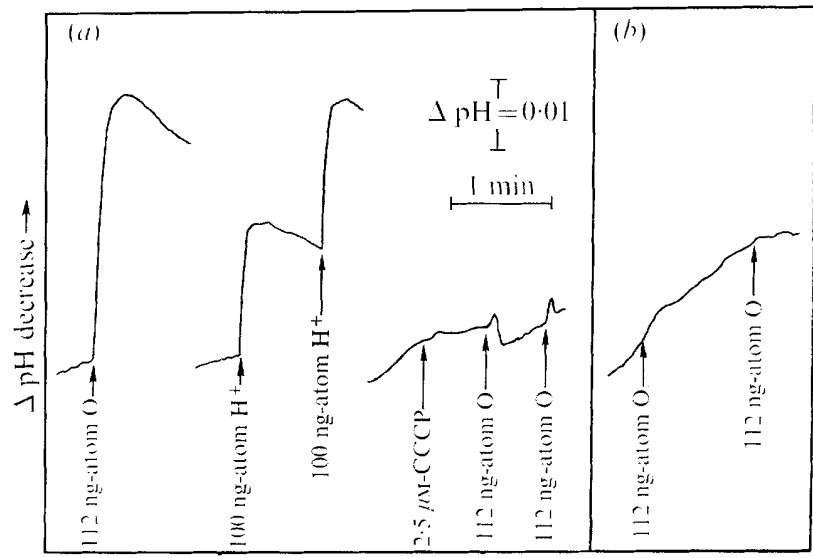

Fig. 4. Changes of $\mathrm{pH}$ in anaerobic suspensions of $S$. faecalis var. zymogenes in response to oxygen pulses: $(a)$ haematin-grown bacteria; $(b)$ bacteria grown without haematin. Bacteria were suspended ( $10 \mathrm{mg}$ dry $\mathrm{wt} \mathrm{ml}^{-1}$ ) in $5 \mathrm{ml}$ of $\mathrm{I}$ mM-glycylglycine $/ 140 \mathrm{~mm}-\mathrm{KCl}$ buffer $\mathrm{pH} 7.0$. Sodium DL-lactate $(5 \mu \mathrm{mol})$ and valinomycin $(4.5 \mathrm{nmol})$ were added prior to pulsing with oxygen-saturated buffer. Carbonyl cyanide $m$-chlorophenylhydrazone (CCCP; $12.25 \mathrm{nmol}$ ) was added at the time indicated.

not take into account any oxygen uptake mediated by the soluble, flavoprotein electron transport system in S. faecalis (Dolin, 1955). The error due to neglecting this component would be very small since there is apparently a very low rate of lactate respiration by this system alone (Table 2). Bacteria grown without added haematin do not usually show any oxygen-induced proton pulses although the low activity of membrane-bound NADH oxidase and the small CCCP-sensitive component of lactate respiration may indicate that even these bacteria have traces of a cytochrome system due possibly to haem compounds present in the yeast extract used in the medium. This could account for the occasional finding of small and sluggish proton pulses in non-haem-grown bacteria at high cell densities.

The stimulation of the rate of oxygen uptake by CCCP and gramicidin during glucose oxidation is further evidence of respiratory control in haematin-grown bacteria. The oxidation of glucose by such bacteria is presumably mediated in part by the membrane-bound NADH oxidase system and in part by the soluble, flavoprotein oxidase. Glucose respiration by non-haem-grown bacteria, which must be mediated almost solely by the soluble oxidase system, was inhibited to to $20 \%$ by the uncoupling agents. If this same inhibition affects the soluble oxidase component of glucose respiration in the haematin-grown bacteria then the 
stimulation of the membrane-bound component by uncouplers may be even greater than the 20 to $25 \%$ observed.

The high rate of lactate oxidation by haematin-grown bacteria and its sensitivity to inhibition by uncoupling agents markedly contrasts with the situation in bacteria grown without haematin. Harold \& Levin (1974) have shown that lactate accumulation by $S$. faecalis is a function of the $\mathrm{pH}$ difference between the cell interior and the medium and is inhibited by ionophores which dissipate the $\mathrm{pH}$ gradient. The increased rate of lactate respiration in haematin-grown bacteria is probably due to an enhanced $\mathrm{pH}$ gradient due to the oxygen-stimulated proton extrusion. The inhibition of uptake by uncoupling agents would greatly outweigh any stimulatory effects on subsequent oxidation by the membranebound oxidase system.

One unresolved problem concerns the mechanism of lactate oxidation in the haematingrown bacteria. No evidence has been obtained from the present study that lactate can be oxidized directly by the membrane-bound oxidase system. Membrane suspensions showed no oxygen uptake with added lactate (in contrast to a very active uptake with NADH) nor was there any detectable cytochrome reduction by lactate in membrane suspensions although lactate fully reduced the cytochromes in whole cells. There was no lactate:DCPIP oxidoreductase activity in either the membrane fraction or the soluble fraction of haem-grown cells (even in the presence of phenazine methosulphate) in contrast to the high NADH: DCPIP oxidoreductase activity in the membrane fraction. Therefore, either the lactate oxidase system is very labile or lactate oxidation in whole cells is due to the combined action of a soluble, NAD-dependent lactate dehydrogenase and the NADH oxidase system. The NAD-dependent lactate dehydrogenase of $S$. faecalis has an obligatory requirement for fructose-1,6-diphosphate for activity (Wittenberger \& Angelo, 1970). The concentration of this activator is unlikely to be very high in bacteria grown in the absence of glucose so the enzymic mechanism responsible for the high rate of lactate oxidation found in haematingrown bacteria is in need of further investigation.

\section{REFERENCES}

Bryan-Jones, D. G. \& WhitTenbury, R. (1969). Haematin-dependent oxidative phosphorylation in Streptococcus faecalis. Journal of General Microbiology 58, 247-26o.

Dolin, M. I. (1955). The diphosphopyridine nucleotide (DPNH)-oxidising enzymes of Streptococcus faecalis. II. The enzymes utilising oxygen, cytochrome $c$, peroxide and 2,6-dichlorophenolindophenol as oxidants. Archives of Biochemistry and Biophysics 55, 4I5-435.

Gel'man, N. S., Lukoyanova, M. A. \& OstrovskiI, D. N. (1967). Respiration and Phosphorylation of Bacteria. New York: Plenum Press.

Gray, C. T., Wimpenny, J. W. T., Hughes, D. E. \& Mossman, M. R. (I966). Regulation of metabolism in facultative bacteria. I. Structural and functional changes in Escherichia coli associated with shifts between the aerobic and anaerobic states. Biochimica et biophysica acta 117, 22-32.

Harold, F. M. \& Levin, E. (1974). Lactic acid translocation. The terminal step in glycolysis by Streptococcus faecalis. Journal of Bacteriology I17, 1 14I-I148.

HugHes, D. E. (I95I). A press for disrupting bacteria and other micro-organisms. British Journal of Experimental Pathology 32, 97-109.

Jones, C. W., Brice, J. M., Downs, A. J. \& Drozd, J. W. (1975). Bacterial respiration-linked proton translocation and its relationship to respiratory chain composition. European Journal of Biochemistry 52, 265-271.
LAWFORD, H. G. \& HADDOCK, B. A. (I973). Respiration-driven proton translocation in Escherichia coli. Biochemical Journal 136, $217-220$.

Lowry, O. H., Rosebrough, N. J., Farr, A. L. \& RANDALL, R. J. (195I). Protein measurement with the Folin phenol reagent. Journal of Biological Chemistry I93, 265-275.

Ritchey, T. W. \& Seeley, H. W. (1974). Cytochromes in Streptococcus faecalis var. zymogenes grown in a haematin-containing medium. Journal of General Microbiology 85, 220-228.

Ritchey, T. W. \& Seeley, H. W. (1976). Distribution of cytochrome-like respiration in streptococci. Journal of General Microbiology 93, I95203.

Scholes, P. \& Mitchell, P. (1970). Respirationdriven proton translocation in Micrococcus denitrificans. Journal of Bioenergetics I, 309323.

SiJPeSteiJn, A. K. (1970). Induction of cytochrome formation and stimulation of oxidative dissimilation by hemin in Streptococcus lactis and Leuconostoc mesenteroides. Antonie van Leeuwenhoek 36, 335-348.

Wittenberger, C. L. \& Angelo, N. (1970). Purification and properties of a fructose-1,6-diphosphate activated lactate dehydrogenase from Streptococcus faecalis. Journal of Bacteriology ror, $77^{-}$ 724 . 